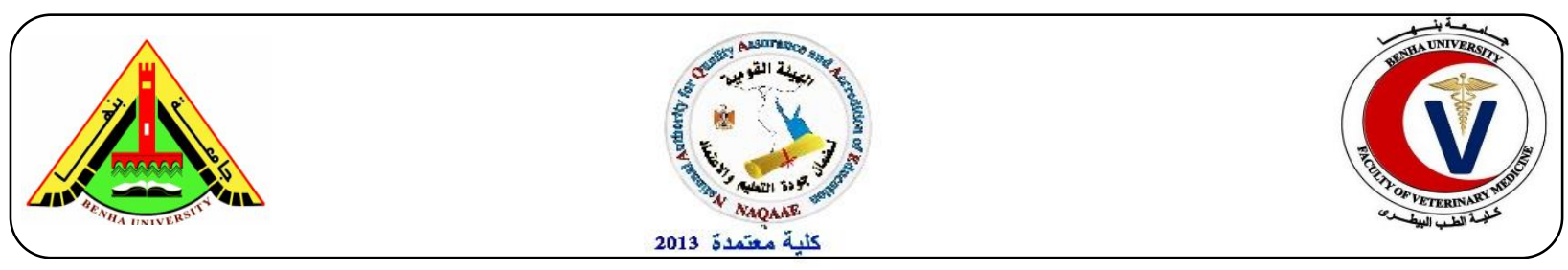

\title{
Clinico-biochemical, oxidative markers and trace elements changes in cows with ketosis
}

Ghanem, M.M., Fares, A., Abdel-Raof, Y.M., El-Attar, H.E.

Department of Animal Medicine, Fac. Vet Medicine, Benha University

Corresponding author: mohamed.ghanem@fvtm.bu.edu.eg

\section{A B S T R A C T}

Ketosis was diagnosed in 10 lactating cows in private farm in Qaluabia government based on the blood level of Non-esterified fatty acid (NEFA) and Beta hydroxy butyric acid (BHBA). Another 10 healthy cows with normal NEFA and BHBA were used as control. Clinically, the affected cows had partial or complete anorexia with reduction of rumen movement. Biochemically, there was a significant $(\mathrm{P}<0.05)$ increase in AST, ALT, creatinine in addition to NEFA and BHBA in ketotic group compared to control. On the other hand, there was significant decrease $(\mathrm{P}<0.05)$ in triacyl glyceride, albumin, copper and zinc. The oxidative stress markers showed significant increase $(\mathrm{P}<0.05)$ in MDA concentration and significant decrease in SOD activity. It was concluded that ketosis is related to clinical, biochemical, oxidative stress and reduced serum $\mathrm{Cu}$ and $\mathrm{Zn}$ levels. It is recommended to add trace elements, specially serum $\mathrm{Cu}$ and $\mathrm{Zn}$ in the periparturient period.

Keywords: Anti-oxidant, biochemical, copper, ketosis, zinc.

(http://www.bvmi.bu.edu.eg)

(BVMJ-33(2: 224-236, DECEMBER, 2017)

\section{INTRODUCTION}

Pregnancy and lactation are physiological statuses considered to modify metabolism in animals and induce stress (Iriadam, 2007).

Ketosis is a major metabolic disease of dairy cows in early lactation, which develops when dairy cows fall into a condition of excessively negative energy balance caused by insufficient dietary intake and generous lactation (Xuet al., 2008). New cows with serum BHBA levels of $\geq 1800 \mu \mathrm{mol} / \mathrm{L}$ have an expected drain loss of $300 \mathrm{~kg}$ for that lactation (Duffield et al., 2009). Subclinical ketosis (serum BHB between 1200 to $1400 \mathrm{micromol} / \mathrm{l}$ ) in the first or second week after calving is associated with increased risk of displaced abomasum, metritis, clinical ketosis, endometritis, prolonged postpartum an ovulation, increased severity of mastitis, and lower milk production in early lactation. There are several validated and practical tools for cow-side measurement of ketosis (LeBlanc., 2010). The periparturient period is important in terms of its influence on health and subsequent performance of dairy cows, since cows develop serious metabolic and physiological changes during these periods (Tanka et al., 2011).

Ketosis is a common metabolic disorder in high yielding dairy cows. During peak lactation period, high yielding dairy cows enter a stage of negative energy balance due to energy output required for milk production is higher than the energy obtained from the consumed feed. Due to negative energy balance there is decrease in 
serum concentration of glucose and insulin that will in-turn leads to mobilization of adipose tissue with which consequently increases serum concentrations of nonesterified fatty acids.

An adequate supply of macro and micronutrients, such as trace element (e.g., $\mathrm{Zn}, \mathrm{Mn}, \mathrm{Cu}, \mathrm{Co}$ ), is important for ensuring an optimal transition from pregnancy to lactation (Andrieu, 2008). For instance, trace element has critical roles in a variety of physiological process, particularly antioxidant defense, and a deficiency may depress immunity especially in peripartal or transition cows (Spears and Weiss, 2008). it is conceivable that trace element has beneficial effects on oxidative stress and inflammation e.g., can help increase overall health and epithelial tissue integrity while reducing the energy required to maintain these systems and consequently improving available energy concluded by Nayeri et al., (2014).

Bovine ketosis occurs in dairy cows suffer from NEB which results in high mobilization of lipids from body fat reserves, leads to fatty liver infiltration (Djoković et al., 2016). Therefore, the use of hepatic enzyme, could be valuable markers for occurrence of ketosis. This study work aimed to monitor the clinical, biochemical and oxidative markers changes in dairy cows 3-4 weeks postpartum. Further aim was to assess the copper and zinc status during this period.

\section{MATERIAL AND METHODS}

\subsection{Animals and study design:}

This study was carried out on 20 Holstein-Friesian dairy cows in a private farm in Qalubia governorate aged between 3-7 years during post parturient period (3rd-4th weeks postpartum). The average daily milk production was $21.51 \pm 2.96 \mathrm{~kg}$. According to colorimetric enzymatic method for diagnosis of ketosis which measure the serum BHBA levels, at a cutoff point of serum BHBA $\geq 1.200 \mathrm{mmol}$ and clinical examination. The cows were classified into 2 groups:

Group 1: included non - ketotic cows $(n=10)$ that were apparently healthy by clinical examination and negative with colorimetric enzymatic method.

Group 2: included ketotic cows $(n=10)$ that were positive with colorimetric enzymatic method. Cows were fed daily on diet consisting of $30 \mathrm{Kg}$ barseem, $10-15 \mathrm{~kg}$. corn silage, $5 \mathrm{Kg}$. hay straw and $10-15 \mathrm{~kg}$. concentrates with (17\% protein) per animal.

\subsection{Sampling:}

The blood samples were collected from jugular vein of all cows during postpartum period during the early morning (Kelly,1984). Serum samples were separated, deep frozen and used for biochemical analysis.

\subsection{Clinical examination:}

Clinical examination of all cows was conducted according to Radostits et al., (2007).

\subsection{Biochemical analysis:}

The clear non-hemolyzed serum were used for the quantitative determination of glucose, NEFA, BHBA, insulin, cholesterol, TAG, HDL, albumin, globulin, total protein, creatinine, $\mathrm{Zn}, \mathrm{Cu}, \mathrm{AST}$, ALT, MDA and SOD by using commercial kits.

\subsection{Statistical analysis:}

All statistical analysis was performed using the Sigma Stat 3.1, statistical software (SPSS Inc., Chicago, IL, USA). The difference between the 2 groups was analyzed by using independent-samples $T$. Results were presented as means (M) \pm standard errors (S.E.) The significance was determined when $\mathrm{P}<0.05$. 


\section{RESULTS}

\subsection{Clinical findings}

Clinical examination revealed partial anorexia (refuse to eat concentrate) was observed in three ketotic cows. Acetone odor was detected in breath in only one clinical cow. Scanty firm feces were observed in two ketotic cows. A reduction in milk yield was observed in all ketotic cows. The body temperature, respiratory rates and pulse rate of ketotic cows were not significantly changed. The ruminal movements showed a significant decrease in ketotic and control cows. The average of daily milk production in healthy cows was $21.51 \pm 2.96 \mathrm{~kg} / \mathrm{day}$, while ketotic cows showed $4.7 \%$ reduction in milk production. The ruminal movements of ketotic cows showed a significant decrease $(\mathrm{P}<0.05)$ than control. The mucous membrane of ketotic cows was pale compared with rosy red color of control.

\subsection{Biochemical changes:}

Serum glucose levels showed anon significant $(P \geq 0.05)$ decrease in ketotic cows than control. Serum BHBA and NEFA levels revealed a significant $(P<0.05)$ increase in ketotic cows than control. the hormonal profile, serum insulin levels showed a significant $(P<0.05)$ decreased in ketotic cows than control. The lipid profile, serum TAG levels showed a significant $(P<0.05)$ decreased in ketotic cows than control. serum cholesterol levels showed a non-significant increase in ketotic cows than control Serum HDL levels showed a non-significant decrease in ketotic cows than control. Serum TP and globulin levels revealed anon significant decrease in ketotic cows than control. Serum albumin levels showed a significant $(P<0.05)$ decrease in ketotic cows than control. Regarding the enzymatic functions, serum AST and ALT activity showed significant
$(P<0.05))$ increase in ketotic cows than control. Regarding the kidney functions, serum creatinine levels showed a significant $(P<0.05)$ increase in ketotic cows than control. Regarding the serum trace element, zinc and copper showed a significant $(P<0.05)$ decrease in ketotic cow than control. Regarding the oxidative stress markers, serum MDA levels showed a significant $(P<0.05)$ increase in ketotic cow than control cows, whereas; SOD level showed a significant $(P<0.5)$ decrease in ketotic cow than control cows.

\section{DISCUSSION}

All cases of ketosis were recorded in cows during 3 to 4 weeks post-partum. These results are comparable to previous investigations (Andersson and Emanuelson, 1985 and Oetzel, 2004). This could be due to peak milk production during this period (Holtenius and Holtenius, 1996). The body temperature, respiratory rates and pulse rate of ketotic cows showed no significant change compared with ketotic and control cows. These results are similar to what remarked by Issi et al. (2016). Moreover, Asrat et al., (2013) noted no significant change in body temperature, respiratory rate and pulse rate in ketotic cows compared with control. On the other hand, the ruminal movements showed a significant decrease in ketotic compared with control cows. The ruminal stasis observed in ketotic cows is similar to that noted by Dar et al., (2014). Additionally, Youssef et al., (2010), Bali et al., (2016) and Ghanem et al., (2016) remarked a significant decrease of ruminal movement in clinical ketotic cows compared with healthy buffaloes. Depressed ruminal motility could be attributed to the excessive generation of ketone bodies. Ketones bodies are reported to affect ruminal motility causing incomplete and depressed ruminal contraction (Lean et al.,1992). Inhibition of ruminal stimulants 
such as cholecystokinin hormone which stimulates ruminal emptying may explain the presence of ruminal stasis in ketotic buffaloes (Youssef et al., 2010).

Regarding the biochemical analysis of serum glucose levels showed a nonsignificant decrease in ketotic cows compared with control cows. This result agreed with that recorded by Ghanem et al. (2012). On the contrary, Sun et al., (2014) and Li et al., (2016). Zhang et al., (2009) observed that serum glucose levels were lower in ketotic cows than control cows. Decreased blood glucose levels could be attributed to an increased mammary gland activity in lactose synthesis as well as to a decreased hepatocyte activity to synthesize glucose through gluconeogenesis under lipomobilization and lipogenesis in the liver (Djoković et al., 2010 and Djoković et al., 2014). Decreased blood glucose levels could also have attributed to the intake of low energy diet (Bremmer et al., 2000), especially at the early stage of lactation when a high rate of glucose utilization in the mammary gland is required (Nazifi et al., 2008).

Serum NEFA levels showed a significant increase in ketotic cows compared with control cows. This result agreed with Li et al., (2016). Moreover, Đoković et al., (2012) and $\mathrm{Xu}$ et al., (2014) observed a significant increase in serum NEFA levels in ketotic cows than control. NEFA concentration reflects the magnitude of fat mobilization from body reserves and reflects the energy and dry matter intake (Adewuyi et al., 2005). Blood concentration of NEFA considered as the best indicator of NEB and of the lipomobilization (Civelek et al., 2011 and Đjoković et al., 2016). The increase of NEFA could be attributed to an increase in lipolysis as a result of stimulation of hormone-sensitive lipase in adipose tissue due to hypoinsulinemia (Lewis et al., 2002).

Serum BHBA levels showed significant increase in ketotic cows compared with control cows. This result agreed with that recorded by Zhang et al. 2013; Sun et al. 2014; Marutsova et al. (2015)and Li et al. (2016) in ketotic cows recorded a significant increase in serum BHBA levels in ketotic cows compared with control cows. Dairy cows experience a NEB because the drain of energy for milk production exceeds the energy uptake from the ingested feed stuff; this imbalance leads to mobilization of body fat reserves in the form of fatty acids, this result in an increase in ketone body production in the liver (Zhang et al., 2009). Blood BHBA originates from the liver (due to incomplete oxidation of fatty acids) (Oetzel., 2007). Low dry matter intake and increased lactational demand for energy result in propionate deficiency which leads to a lack of oxaloacetate used to convert acetate, butyrate and NEFA to energy in the tricarboxylic acid cycle. As a result, the acetyl-coenzyme A synthesized from acetate, butyrate and NEFA cannot enter into the tricarboxylic acid cycle and combine together to form ketone bodies (acetone, acetoacetate and BHBA) (Goff and Horst.,1997and Kara., 2009). NEFA and BHBA are products of fat catabolism that can supply energy to the body. Their increased levels in blood are symbols of NEB, which predict a great amount of fat mobilization and used as specific indicators for the occurrence of ketosis in cattle (Ospina et al., 2010; Asi et al., 2011 and González et al., 2011).

Serum insulin levels showed a significant decrease in ketotic cows compared with control cows. Decreased serum insulin in ketotic cows is agreeable to that recorded by Sadeghi et al. 2011 and Djoković et al. 
2009 and Xia et al. 2010.Moreover, the decreased serum insulin in ketotic cows is agreeable to that recorded by Ahmad et al., (2005); and Teli and Ali, (2007) in ketotic buffaloes. Decreased serum insulin levels could be attributed to the decreased ability of $\beta$-cells of the endocrine pancreas to synthesize and release insulin (Dokovic et al., 1998 and Djoković et al., 2009). Low plasma insulin concentration reduces glucose uptake by non - mammary extrahepatic tissue and makes glucose available for uptake by the mammary gland which is not responsive to insulin (Bauman.,2000). Decreased insulin concentrations also promote the release of NEFA by the adipose tissue through hormone-sensitive lipase (McGuire et al., 1995). Insufficient blood glucose levels induce a decline in plasma insulin, and lipomobilization as NEFA (Block and Sanchez.,2000). Insulin is low in type I diabetes because of a pancreatic defect, but in type II ketosis insulin is low because of chronic hypoglycemia due to a shortage of glucose precursors (Oetzel, 2007).

Serum TG levels revealed anon significant decrease in ketotic cows compared with control group. The non-significant decrease serum TG levels in ketotic cows are agreeable to that recorded by (Djoković et al., 2007 and González et al., 2011) and Doković et al., (2012). TG accumulates in the liver cells of ketotic cows and causes their blood values to decrease (Đoković et al.,2005; Djoaković et al., 2013 and Đoković et al., 2016). Reichel and Sokoi, (1987) and Veenhuizen et al., (1991) attributed the decrease in blood TG to the significant increase of FFAs concentrations in the blood that causes an increase of the content of lipids in the hepatocytes (fatty liver). serum cholesterol levels showed a significant increase in ketotic cows compared with control cows. This result is agreeable to that. Anantwar and Singh,
(1993) reported that there was an increase in cholesterol levels in ketotic animals. On the contrary Li et al., (2016) and Youssef et al., (2010) reported decrease cholesterol levels in ketosis could be attributed to mild liver steatosis which causes a decrease in cholesterol formation in the liver (Grummer.,1995). Increased accumulation of triglycerides and cholesterol in hepatocytes in the puerperal ketotic cows probably linked to a depleted liver synthesis of VLDL (Holtenius.,1989)

Serum HDL levels showed a nonsignificant decreased in ketotic cows compared with control cows. Decreased HDL may be attributed to depressed lipoprotein lipase (LPL) as there is a positive association between LPL and HDLcholesterol (Cheung et al.,2003). Since LPL is insulin dependent, the depression of LPL activity may be due to decrease in blood insulin and insulin resistance which also occur in ketosis (Herrera et al., 1990).

Serum TP and globulin levels revealed anon significant decrease in ketotic cows compared with control one. However, albumin levels showed a significant decrease in ketotic cows compared with control cows. The decreased liver synthesis of albumin is induced by the development of fatty liver infiltration (Lubojacka et al., 2005).

Serum AST activity showed a significant decrease in ketotic cows compared with control cows. This result is coincided with (Djoković et al., 2016) who recorded that AST is a non-specific liver enzyme. However, Li et al., (2016) in cows and by Youssef et al., (2010) in buffaloes. Sevinc et al. (2001), Doković et al. (2012), Xu et al., (2014) and Shin et al., (2015) recorded a significant increase in serum AST levels in ketotic cows than healthy cows. Blood activities of AST are correlated 
with the degree of fatty infiltration in the liver.

Serum ALT activity showed a significant increase in ketotic cows compared with control cows this result is parallel with that recorded by $\mathrm{Li}$ et al. (2016) who observed a significant increase of ALT in ketotic cows and in ketotic buffaloes (Youssef et al.,2010 and Bali et al.,2016). On the other hand, Stojević et al., (2005) considered that the role of ALT in predicting liver damage in ketosis is insignificant.

The significant increase in serum creatinine in ketotic cows was parallel with that recorded by Issi et al., (2016) who attributed that to the partial damage of nephrons.

In ketotic cows, serum $\mathrm{Zn}$ levels showed a significant decrease than control cows. This result coincided with that recorded by Zhang et al., (2010) who noted that the serum concentrations of $\mathrm{Zn}$ were significantly decreased in ketotic cows than control cows. It was observed that, after calving, zinc concentration showed a significant negative correlation with MDA concentration concluded that by Karimi et al., (2015). Therefore, the role of $\mathrm{Zn}$ deficiency in ketotic cows could be related to its antioxidant activities. In the antioxidant system, $\mathrm{Zn}$ is a component of $\mathrm{Cu}-\mathrm{Zn} \mathrm{SOD}$. Zinc also induces synthesis of metallothionein, a metal binding protein that may scavenge hydroxide radicals (Spears and Weiss, 2008). In addition, Zinc plays an important role in the synthesis, storage, and secretion of insulin as well as conformational integrity of insulin in the hexameric form which affects the ability of islet cells to produce and secret insulin (Duzguner and Kaya, 2007). Moreover, Zinc deficient animals have reduced serum insulin content. Therefore, insufficient zinc may influence the generation and metabolism of BHBA by reducing the secretion of insulin in dairy cows (Karimi et al., 2015).

Serum $\mathrm{Cu}$ levels showed a significant decrease in ketotic cows than control cows. This result coincides with that recorded by Kaya et al., (2016) who noted that $\mathrm{Cu}$ level was found significantly lower in ketotic dairy cows compared to healthy dairy cows. On the other hand, there was no significant difference observed for serum $\mathrm{Cu}$ concentration between healthy and subclinical ketotic dairy cows (Zhang et al.,2010). The reduction of $\mathrm{Cu}$ level in the serum of clinically ketotic cows suggest its role in carbohydrate metabolism (Kozat., 2006). In addition, $\mathrm{Cu}$ is involved in the production of antioxidants via its role in the $\mathrm{Cu}-\mathrm{Zn}$ superoxide dismutase (SOD) and ceruloplasmin (Spears and Weiss, 2008). In dairy cows, low levels of $\mathrm{Cu}$ have been observed to be related with low drain quality with expanded physical cell tally, expanded defenselessness to mastitis, diminished sustain admission, loss of multiplication, development sorrow and weakened insusceptible status, diminish fruitfulness, delayed work and fetus removal (Enjalbert et al., 2006).

Regarding the oxidant-antioxidant activity, Serum MDA levels showed a significant increase in ketotic compared with control cows, which is agreeable to that recorded by Li et al., (2016) in cows and (Youssef et al., 2010) in ketotic buffaloes. Additionally, Xu et al. (2014) recorded a significant increase in serum MDA levels in ketotic cows compared with that of control. A great amount of NEFAs from fat mobilization of dairy cows affected ketosis may produce a great deal of oxygen radical, such as ROS, which can initiate oxidative stress (Schönfeld and Wojtczak, 2008). In humans, increase blood KBs could increase the blood lipid peroxidation which 
could be determined by examination of plasma level of MDA (Jain et al.,1999). MDA is a degradation product of lipid peroxidation after exposure to ROS and its level in the blood may be considered as an assessing indicator of lipid peroxidation (Turk et al., 2008). Additionally, Mudron et $a l .$, (1999) attributed the increased MDA in the cows with fatty livers to increase in the intensity of hepatic lipoperoxidative processes and a low antioxidative status. Serum SOD levels showed a significant decrease in ketotic cows compared with that of control cows. This result is agreeable to that recorded by Li et al., (2016) and that recorded by Al-Qudah, (2011) in pregnancy toxemic ewes. SOD activity of diabetic pregnant women showed significant decrease vs normal pregnant women and non-pregnant group (Djordjevic et al., 2004). Decreased SOD levels explained by the severe damage that occurred in the erythrocyte membrane and other cellular structures depending on an inability to fully detoxify oxygen free radicals (Gurdogan et al., 2014). However, $\mathrm{Xu}$ et al., (2014) observed a significantly increased SOD levels in ketotic cows due to enhanced antioxidative ability. Pedernera et al., (2010) concluded that oxidants-antioxidants imbalance, an excess of oxidants and/or a depletion of antioxidants, can lead to oxidative stress. Oxidative stress occurs when an imbalance happens between the oxidative system and antioxidative system, which cause cellular damage (Abuelo et al., 2013). The oxidative damage could also be a contributing factor for damage to the hepatic cells and release of hepatic enzymes. The reduction in $\mathrm{Cu}$ and $\mathrm{zn}$ levels could represent contributing factors for reduction of anti-oxidant capapcity since they are members on $\mathrm{Cu}$-zn superoxide dismutase system (Spears and Weiss, 2008).

Finally, Ketosis is an essential metabolic disorder in Holstein- Friesian dairy cows in Egypt which is associated with reduction in milk yield, several biochemical changes and increased oxidative stress markers which reflect the negative impact of ketosis on dairy cows. The disease was also associated with trace element deficiency such as $\mathrm{Cu}$ and $\mathrm{Zn}$. Therefore, it is recommended to add trace elements, particularly $\mathrm{Cu}$ and $\mathrm{Zn}$ during the critical stage of ketosis (3-4 weeks postpartum).

\section{REFERENCES}

Abuelo, A., Hernandez, J., Benedito, J.L., Castillo, C. 2013. Oxidative stress index (OSi) as a new tool to assess redox status in dairy cattle during the transition period. Animal 7, 13741378.

Adewuyi, A.A., Gruys, E., Van Eerdenburg, F.J.C.M. 2005. Non-esterified fatty acids (NEFA) in dairy cattle. A review. Vet Q 27, 117-126.

Ahmad, S. 2005. Evaluation of various therapeutic regimens in bubaline ketosis. Compendium of National Symposium and XXIII Annual Convention of The Indian Society for Veterinary Medicine (ISVM) held at Durg. pp. 44.

Al-Qudah, K.M. 2011. Oxidant and antioxidant profile of hyperketonemic ewes affected by pregnancy toxemia. Veterinary Clinical Pathology, 40 (1): 60-65.

Anantwar, L.G., Singh, B. 1993. Epidemiology, clinicopathology and treatment of clinical ketosis in buffaloes (Bubalusbubalis). Indian Veterinary Journal, 70: 152-156.

Andersson, L., Lundstrom, K. 1985. Effect of feeding silage with high butyric acid content on ketone body formation and milk yield in postparturient dairy cows. Zentralblattfur Veterinarmedizin Reihe A, 32, 15-23. 
Andrieu, S. 2008. Is there a role for organic trace element supplements in transition cow health. Vet. J. 176:77-83.

Asl, A.N.; Nazifi, S.; Ghasrodashti, A.R., Olyaee, A. 2011. Prevalence of subclinical ketosis in dairy cattle in the Southwestern Iran and detection of cut off point for NEFA and glucose concentrations for diagnosis of subclinical ketosis. Preventive Veterinary Medicine, 100(1): 38-43.

Asrat, M., Tadesse, G.H., Gounder, R.V., Nagappan, R. 2013. Prevalence and Treatment of Ketosis in Dairy Cows in and Around Addis Ababa, Ethiopi. British Journal of Dairy Sciences 3, 26-30.

Bali, G., Hussain, K., Razzaque, W.A.A., Sharma, U., Beigh, S.A. 2016. Clinicobiochemical studies of ketosis in buffalo (bubalus bubalis). Buffalo bulletin, 35 (1): 27-32. ketosis. Turk. J. Vet. Anim. Sci.40, 47-52.

Bauman, D.E. 2000. Regulation of nutrient partitioning during lactation: homeostasis and homeorhesis revisited, in: Cronje, P.J. (Ed.), Ruminant Physiology: Digestion, Metabolism and Growth and Reproduction, CAB Publishing, New York, Pp. 311-327.

Block, E., Sanchez, W. 2000. Special nutritional needs of the transition cow. Middle South Nutrition Conference, Dallas, TX.

Bremmer, D.R., Trower, S.L., Bertics, S.J., Besong, S.A., Bernabucci, U., Grummer, R.R. 2000. Etiology of fatty liver in dairy cattle: effects of nutritional and hormonal status on hepatic microsomal triglyceride transfer protein. Journal of dairy science 83, 2239-2251.

Cebra, C.K.; Garry, F.B.; Getzy, D.M.; Fettman. M.J. 1997. Hepatic lipidosis in anorectic, lactating Holstein cattle: retrospective study of serum biochemical abnormalities. Journal of
Veterinary Internal Medicine, 11 (4): 231-237.

Cheung, M.C., Sibley, S.D., Palmer, J.P., Oram, J.F., Brunzell, J.D. 2003. Lipoprotein lipase and hepatic lipase: their relationship with HDL subspecies Lp (A-I) and Lp (A-I,A-II). Journal of lipid research 44, 1552-1558.

Civelek, T.; Aydin, I.; Cingi, C.C.; Yilmaz, O., Kabu, M. 2011. Serum nonesterified fatty acids and betahydroxybutyrate in dairy cows with retained placenta. Pakistan Veterinary Journal, 31(4): 341-344.

Dar, K.H., Ansari, M.M., Tantary, H.A., Baba, M.A., Ashraf, I. 2014. Studies on Efficacy of Therapeutic Protocols for Ketosis in Dairy Cows. Inter J Vet Sci. 3, 147-150.

Đjoković, R., Cincović, M., Kurćubić, V., Petrović, M., Lalović, M., Jašović, B., Stanimirovi, Z. 2014. Endocrine and Metabolic Status of Dairy Cows during Transition Period. Thai J Vet Med.44, 59-66.

Đjoković, R., Ilić, Z., Kurćubić, V., Petrović, M.P., Petrović, V.C., Milošević, B., Omerović, I. 2016. Determination metabolic and nutritional status in dairy cows during early and midlactation. Biotechnology in Animal Husbandry 32, 1-8.

DjoKovic, R., Kurčubić, V., Ilić, Z., Cincović, M., Petrović, M., Fratric, N., Jasovic, B. 2013. Evaluation of metabolic status in Simmental dairy cows during late pregnancy and early lactation. Veterinarski Arhiv83, 593602.

Djoković, R.; Šamanc, H. Bojkovski, J.; Fratrić, N. 2010. Blood concentrations of thyroid hormones and lipids of dairy cows in transitional period. Lucrăristi Inłifice Medicină Veterinară, vol. xliii (2):34-40.

Djoković, R.; Šamanc, H.; Ilić, Z.; Kurćubić, V. 2009. Blood glucose, insulin and 
inorganic phosphorus in healthy and ketotic dairy cows after intravenous infusion of glucose solution. Acta Veterinaria Brno, 78(3):449- 453.

Djoković, R.; Šamanc, H.; Jovanović, M.; Nikolić, Z. 2007. Blood concentrations of thyroid hormones and lipids in the liver in dairy cows in transitional period. Acta Veterinaria Brno, 76(4): 525-532.

Djordjevic, A.; Spasic, S.; JovanovicGalovic, A.; Djordjevic, R.; GruborLajsic, G. 2004. Oxidative stress in diabetic pregnancy: SOD, CAT and GSH-PX activity and lipid peroxidation products. Journal of Maternal-Fetal and Neonatal Medicine, 16(6):367-72.

Đoković, R.; Kurčubić, V.; Ilić, Z.; Cincović, M.; Davidov, I.; Petrović, M. D.; Trifković, J. 2014. Changes in blood values of glucose, insulin and inorganic phosphorus in healthy and ketotic cows during an intravenous glucose tolerance test. Biotechnology in Animal Husbandry, 30 (4): 571-578.

Đoković, R.; Šamanc, H.; BoškovićBogosavljević, S.; Radović, V. 2005. Changes of characteristic blood parameters in ketotic cows. Veterinarski Glasnik, 59 (1-2):221228.

Dokovic, R.; Samanc, H.; Jevetic, S.; Vitorovic, D.; Gutic, M.; Boskovic, B.S.; Petrovic, M.; Radenkovic, B. 1998. Changes in blood concentrations of insulin, glucose and inorganic phosphors in healthy and ketotic cows following I.V. administration of glucose solution. Veterinary Glasnik, 52:373-383.

Đoković. R.; Šamanc, H.; Petrović, M.D.; Ilić, Z.; Kurćubić, V. 2012. Relationship among blood metabolites and lipid content in the liver in transitional Dairy Cows.
Biotechnology in Animal Husbandry, 28 (4):705-714.

Duffield, T.F.; Lissemore, K.D.; McBride, B.W.; Leslie, K.E. 2009. Impact of hyperketonemia in early lactation dairy cows on health and production. Journal of Dairy Science, 92(2):571-580.

Duzguner, V.; Kaya S. 2007. Effect of zinc on the lipid peroxidation and the antioxidant defense systems of the alloxan-induced diabetic rabbits. Free Radic. Biol. Med.; 42(10):1481-6.

Enjalbert, F., Lebreton, P., Salat, O. 2006. Effect of copper, zinc and selenium ststuson performance and health in commercial dairy and beef herds: retrospective study. J. Anim. Physiol. Anim. Nutr., 90: 459-466.

Forenbacher, S. 1993. Kliničkapatologij aprobave imijenet varido maćihživotinja. Svezak II Jetra. Školskaknjiga, Zagreb. pp. 101-112.

Ghanem, M.M.; Mahmoud, M.E.; Abd ElRaof, Y.M.; El-Attar, H.M. 2016. Alterations in biochemical parameters and hepatic ultrasonography with reference to oxidant injury in ketotic dairy cows. Banha Veterinary Medical Journal, 31(2): 231-240.

Ghanem, M.M., Mahmoud, M.E., Abd ElRaof, Y.M.; El-Attar, H.M. 2012. Metabolic profile test for monitoring the clinical, haematological and biochemical alterations in cattle during periparturient period. Banha Veterinary Medical Journal 23, 13-23.

Goff, J.P.; Horst, R.L. 1997. Physiological changes at parturition and their relationship to metabolic disorders. Journal of Dairy Science, 80(7):12601268.

Gonzalez, F.D., Muino, R., Pereira, V., Campos, R.; Benedito, J.L., 2011. Relationship among blood indicators of lipomobilization and hepatic function during early lactation in high-yielding 
dairy cows. Journal of veterinary science; 12, 251-255.

Grummer, R.R., 1995. Impact of changes in organic nutrient metabolism on developing feeding strategies to minimize stress during the transition from late pregnancy to early lactation. J. Anim. Sci.73, 2820-2833.

Gurdogan, F., Balıkçı, E., Yıldız, A., 2014.

Some acute phase proteins, oxidative stress biomarkers and antioxidant enzyme activities in ewes with Pregnancy toxemia. Iranian Journal of Veterinary Research, Shiraz University15, 297-299.

Herdt, T.H.; Leisman, J.S.; Gerloff, B.J.; Emerzy, R.S. 1983. Reduction of serum triacilglycerol-rich lipoprotein concentrations in cows with hepatic lipidosis. American Journal Veterinary Research, 44:293-296.

Herrera, E., Ramos, P., Martin, A. 1990. Control by insulin of adipose tissue lipoprotein lipase activity during late pregnancy in the rat. In Frontiers in Diabetes Research Lessons from Animal Diabetes III, E. Shafrir, Editor SmithGordon, London. vol XI:551554.

Holtenius, P. 1989. Plasma lipids in normal cows around partus and in cows with metabolic disorders with and without fatty liver. Acta Veterinaria Scandinavica, 30(4):441-5.

Holtenius, P., Holtenius, K. 1996. New aspects of ketone bodies in energy metabolism of dairy cows: a review. Zentralbl Veterinarmed A., 43(10):579-587.

Iriadam, M. 2007. Variation in certain haematological and biochemical parameters during the peri-partum period in Kilis does. Small Rum. Res. 73, 54-57.

İssi, M., Gul, Y., Başbuğ, O. 2016. Evaluation of renal and hepatic functions in cattle with subclinical and clinical ketosis. Turk J Vet Anim Sci. 40, 47-52.

Jain, N.C. 1993. Essentials of Veterinary Hematology.5th ed. Lea and Fibiger. Philadelphia, U. S. A.

Jorritsma, R.; Jorritsma, H.; Schukken, Y.H.; Bartlett, P.C.; Wensing, T.; Wentink, G.H. 2001. Prevalence and indicators of postpartum fatty infiltration of the liver in nine commercial dairy herds in the Netherlands. Livestock Production Science, 68(1): 53-60.

Kaneko, J.J. 1989. Clinical Biochemistry of Domestic Animals. 4th Edn., Academic Press, New York, California, USA., Pp: 898.

Kara, Ç., 2009. Sütsı̆̆ır larınınge çişdönemlerindekalsiyumpropiyonatkat kısınınsütverimivebileşimiileketozis, hipokalsemivebazıdölverimiparametrel erineetkileri. The Degree of Doctor of Philosophy Thesis, U.Ü. Veteriner Fakültesi, Bursa, Turkey.

Karimi, N.; Mohri, M; Mohammed, A.; Hesam, A.S.; Mohammed, H. 2015. Relationships between trace elements, oxidative stress and subclinical ketosis during transition period in dairy cows. Irnian Journal of Vet. Sci. and Technology,7(2):64-56.

Kaya, A.; Ozkan, C.; Kozat, S.A.; Kgul,Y.; Ozbek, M. 2016. Evaluation of cobalt, copper, manganese, magnesium and phosphorus levels in cows with clinical ketosis.Pak Vet Journal, 36(2): 236238.

Kohen, R.; Nyska, A. 2002. Oxidation of biological systems: oxidative stress phenomena, antioxidants, redox reactions, and methods of their quantification. Toxicologic Pathology, 30(6):620-50.

Kozat, S. 2006. Importance, necessity and the effects of deficiencies of trace elements in ruminants. J. Health Sci., 9: 58-67. 
Kupczynski, R.; Chudoba-drozdowsk, B. 2002. Values of selected biochemical parameters of cows blood during their drying-off and the beginning of lactation. Electronic Journal of Polish Agricultural Universities, 55:225-231.

Lean, I.J., Bruss, R.L., Baldwin, R.L., Troutt, H.F. 1992. Bovine ketosis: A review II. Biochemistry and prevention. Vet. Bull. 62, 1-14.

LeBlanc, 2010. Monitoring metabolic health of dairy cattle in the transition period. J. Reprod Dev.; 56 suppl: s29-35.

Lewis, G.F., Carpentier, A., Adeli, K., Giacca, A. 2002. Disordered fat storage and mobilization in the pathogenesis of insulin resistance and type 2 diabetes. Endocrine reviews 23, 201-229.

Li, Y., Ding, H.Y., Wang, X.C., Feng, S.B., Li, X.B., Wang, Z., Liu, G.W., Li, X.W. 2016. An association between the level of oxidative stress and the concentrations of NEFA and BHBA in the plasma of ketotic dairy cows. Journal of Animal Physiology and Animal Nutrition. Article first published on line: 14 APR 2016 DOI: 10.1111/jpn.12454.

Lubojacka, V., Pechova, A., Dvorak, R., Drastich, P., Kummer, V., Poul, J. 2005. Liver steatosis following supplementation with fat in dairy cows' diets. Acta Veterinaria Brno74, 217-224.

Marutsova, V.; Binev, R.; Marutsov, P. 2015. Comparative Clinical and Haematological Investigations in Lactating Cows with Subclinical and Clinical Ketosis. Macedonian Veterinary Review, 38 (2): 159-166.

McGuire, M.A., Griinari, J.M., Dwyer, D.A.; Bauman, D.E. 1995. Role of insulin in the regulation of mammary synthesis of fat and protein. Journal of dairy science 78,816-824.
Mudron, P.; Rehage, J.; Qualmann, K.; Sallman, H.P.; Scholz, H. 1999. A study of lipid peroxidation and vitamin $\mathrm{E}$ in dairy cows with hepatic insufficiency. Zentralbl Veterinarmed A, 46(4): 219-224.

Nayeri, U.S.; Sanz, F.D.; Gorden. P.J.; Baumgarg, L.H. 2014. Effect of the ratio of Zinc sulfate on the performance of Holstein cows. J. Dairy Sci.,97(2014), PP.4392-4404.

Nazifi, S., MhebbiFani, M., Rowghani, E., Behlood, M.R. 2008. Studies on the relationship Between Sub-Clinical Ketosis and Liver Injuries Within the First Two Months of Lactation Period in High Producing Iranian Holstein cows: International Journal of Dairy Science3, 29-35.

Oetzel, G.R. 2004. Monitoring and testing dairy herds for metabolic disease. Veterinary clinics of North America: Food animal practice, 20(3):651-674.

Oetzel, G.R. 2007. Herd-level ketosis diagnosis and risk factors. In: Preconference Seminar 7C: Dairy Herd Problem Investigation Strategies: Transition Cow Troubleshooting, 40th Annual Conference of the American Association of Bovine Practitioners, Vancouver, BC, Canada, Pp. 67-91.

Ospina, P.A.; Nydam, D.V.; Stokol, T.; Overton, T.R. 2010. Evaluation of nonesterified fatty acids and betahydroxybutyrate in transition dairy cattle in the northeastern United States: Critical thresholds for prediction of clinical diseases. Journal of Dairy Science, 93(2): 546-554.

Pechova, A.; Llek, J.; Halouzka, R. 1997. Diagnosis and control of the development of hepatic lipidosis in dairy cows in the peri-parturient period. Acta Veterinaria Brno, 66: 235243.

Pedernera, M., Celi, P., Garcia, S.C., Salvin, H.E., Barchia, I.; Fulkerson, W.J., 
2010. Effect of diet, energy balance and milk production on oxidative stress in early-lactating dairy cows grazing pasture. Veterinary journal (London, England: 1997) 186, 352-357.

Radostits, O.M., Gay, C.C., Blood, D.C., Hinchdiff, K.W. 2007. Veterinary Medicine. A Textbook of the Diseases of Cattle, Sheep, Pigs, Goats and Horses 9th ed WB. Saunders, London. pp: 1661-1668.

Reichel, P.; Sokoi, J. 1987. Relationship between lipid content of the liver of cows and some constituents of the blood. Biol. Chem. Ziro. Vyroby. Vet., 23: 53-61.

Sadeghi, N.A., Hassanpour, A., Sabaghsaray, H., Amirisadeghan, S. 2011. Assessment of thyroid hormones, insulin and magnesium in dairy cattle with subclinical ketosis Veterinary Clinical Pathology (Veterinary Journal Tabriz) 5, 1149 1159.

Sahinduran, S., Sezer, K., Buyukoglu, T., Albay, M.K., Karakurum, M.C., 2010. Evaluation of some haematological and biochemical parameters before and after treatment in cows with ketosis and comparison of different treatment methods. J. Anim. Vet. Adv.9, 266271.

Schönfeld, P., Wojtczak, L. 2008. Fatty acids as modulators of the cellular production of reactive oxygen species. Free Radic. Biol. Med. 45, 231-41.

Sevinc, M.; Basoglu, A.; Birdane, F.M., Boydac, M. 2001. Liver function in dairy cows with fatty liver. Revue de médecinevétérinaire, 152: 297-300.

Shin, E.K.; Jeong, J.K.; Choi, I.S.; Kang, H.G.; Hur, T.Y.; Jung, Y.H.; Kim, I.H. 2015. Relationships among ketosis, serum metabolites, body condition, and reproductive outcomes in dairy cows. Theriogenology, 84 (2): 52-260.
Smith, S.B.; Prior, R.L.; Mersmann, H.J. 1983. Interrelation ships between insulin and lipid metabolism in normal and alloxan -diabetic cattle. Journal of Nutrition, 113(5):1002-15.

Spears, J.W.; Weiss, W.P. 2008. Role of antioxidants and trace elements in health and immunity of transition dairy cows. Vet. J., 176: 70-76.

Stojević, Z.; Piršljin, J.; Milinković-Tur, S.; Zdelar-Tuk, M.; Ljubić, B.B. 2005. Activities of AST, ALT and GGT in clinically healthy dairy cows during lactation and in the dry period. Vet Arh, 75(1): 67-73.

Sun, L. W.; Zhang, H. Y.; Wu, L.; Shu, S.; Xia, C.; Xu, C.; Zheng, J.S. 2014. Nuclear magnetic resonance-based plasma metabolic profiling of dairy cows with clinical and subclinical ketosis. Journal of Dairy Science, 97(3):1552-1562

Tanaka M., Kamiya, Y., Suzuki, T., Nakai, Y. 2011. Changes in oxidative status in periparturient dairy cows in hot conditions. Anim. Sci. J. 82, 320-324.

Teli, S.A.; Ali, S.L. 2007. Plasma Glucose and Insulin Profiles in Ketotic Buffaloes. Vet. Scan, Online Vet. 2 (2), Article 19.

Turk, R., Juretic, D., Geres, D., Svetina, A., Turk, N., Flegar-Mestric, Z. 2008. Influence of oxidative stress and metabolic adaptation on PON1 activity and MDA level in transition dairy cows. Animal reproduction science 108, 98-106.

Veenhuizen, J.J., Drackley, J.K., Richard, M.J., Sanderson, T.P., Miller, L.D., Young Veenhuizen, J.W. 1991. Metabolic changes in blood and liver during development and early treatment of experimental fatty liver and ketosis in cows. Journal of dairy science 74, 4238- 4253.

Xia, C.; Wang, Z.; Liu, G. W.; Zhang, H. Y.; Zhang, C.; Xu, C. 2010. Changes of 
Plasma Metabolites, Hormones, and mRNA Expression of Liver PEPCK-C in Spontaneously Ketotic Dairy Cows. Asian-Australasian Journal of Animal Sciences, 23(1): $47-51$.

Xu, C.; Liu, G.W.; Li, X.B.; Xia, C.; Zhang, H.Y.; Wang, Z. 2010. Decreased Complete Oxidation Capacity of Fatty Acid in the Liver of Ketotic Cows. Asian-Australasian Journal of Animal Sciences, 23 (3): 312 - 317.

Xu, C., Shu, S., Xia, C., Wang, B., Zhang, H.Y., Jun, B. 2014. Investigation on the Relationship of Insulin Resistance and Ketosis in Dairy Cows. J. Veterinar. Sci. Technolo.5, 162.

Xu, C.; Wang, Z.; Liu, G.; Li, X.; Xie, G.; Xia, C.; Zhang, H.Y. 2008. Metabolic characteristic of the liver of dairy cows during ketosis based on comparative proteomics. Asian-Australasian Journal of Animal Sciences, 21(7):1003-1010.

Youssef, M.A., El-Khodery, S.A., El-deeb, W.M.; Abou El-Amaiem, W.E. 2010. Ketosis in buffalo (Bubalusbubalis): clinical findings and the associated oxidative stress level. Tropical animal health and production 42, 1771-1777.

Zhang, Z, Liu, G, Li, X., Wang 2010. Evolution of the change of serum Copper and Zinc concentration of dairy cows with subclinical ketosis. Biol Trace Element Res.2010 Dec,138(13):8-12. doi:101007/s12011-009-86064.Epub 2010 jan 26.

Zhang, Z.; Liu, G.; Li, X.; Wang, Z.; Kong, T.; Zghan, N.; Guo, C. 2009. $\beta$ Hydroxybutyrate, glucose, calcium, phosphorus and vitamin $\mathrm{c}$ concentrations in blood of dairy cows with subclinical ketosis during the early lactation. Bull Vet InstPulawy, 53: 71-74.

Zhang, H.; Wu, L.; Xu, C.; Xia, C.; Sun, L.; Shu. S. 2013. Plasma metabolomics profiling of dairy cows affected with ketosis using gas chromatography/mass spectrometry. BMC Vet. Res., 9:186198. 